\title{
Faktor-Faktor yang Memengaruhi Perilaku Komunikasi Penyuluhan Pertanian
}

\author{
Andy Corry Wardhani
}

\begin{abstract}
This research aimed to gain a clear description over some factors which influenced communication process conducted by agricultural facilitators-both partially, and simultaneously. Employing explanatory method of research, a sample of 116 agricultural facilitators from Kabupaten Indramayu, Kabupaten Bandung, and Kabupaten Tasikmalaya was chosen using stratified random sampling. Data was generated from questionnaire and a series of selected interviews. It is found that personal and situational factors affected facilitators communication act in the three regions. Compared with situational factors, personal factors have stronger effect.
\end{abstract}

Kata kunci: proses komunikasi, faktor situasional, faktor personal, penyuluh pertanian.

\section{Pendahuluan}

\subsection{Latar Belakang}

Pada hakikatnya, penyuluhan adalah suatu kegiatan komunikasi. Proses yang dialami oleh mereka yang disuluh sejak mengetahui, memahami, meminati, dan kemudian menerapkannya adalah suatu proses komunikasi. Dari proses komunikasi tersebut peran penyuluh sangat menonjol, agar materi penyuluhan itu dapat diketahui, dipahami dan diterapkan oleh petani. Dalam melakukan perannya, penyuluh seringkali mengalami masalah komunikasi, terutama dalam hal kompetensi komunikasi yang seharusnya dimiliki oleh seorang penyuluh. Untuk mengamati kompetensi ini, dapat diketahui dari perilaku komunikasi penyuluh pertanian tersebut.

Perilaku komunikasi penyuluh terkait dengan beberapa faktor yang mempengaruhinya seperti faktor personal dan faktor situasional. Perilaku komunikasi penyuluh dalam melaksanakan tugasnya merupakan faktor yang dominan dalam keberhasilan suatu kegiatan penyuluhan. Karena itu, memahami faktor-faktor yang berpengaruh pada perilaku komunikasi penyuluh menjadi sangat penting. Selain itu, bentuk dan keterkaitan hubungan antara faktor personal dan faktor situasional dengan perilaku komunikasi penyuluh pertanian dan efeknya terhadap keberhasilan penyuluhan perlu juga untuk diketahui agar dapat disusun program pengembangan penyuluh yang baik.

Penelitian tentang penyuluh, pernah dilakukan oleh Pusat Dinamika Pembangunan Universitas Padjadjaran (PDP Unpad) tahun 2000. Penelitan ini mengungkapkan bahwa perilaku penyuluh pertanian di Jawa Barat, dalam hal kehadiran sebagai pelatih pada Balai Penyuluh Pertanian, hanya mencapai $45 \%$ dari yang direncanakan. Mengenai kelompok tani yang terbina melalui kunjungan 
penyuluh di Jawa Barat, realisasinya hanya $44 \%$. Sedangkan efektivitas kunjungan penyuluh pertanian di Jawa Barat dalam sistem kerja latihan dan kunjungan prosentasenya kecil yaitu $11 \%$.

Dari observasi awal pada Dinas Pertanian Tanaman Provinsi Jawa Barat, diperoleh gambaran pula bahwa kinerja penyuluh pertanian di Jawa Barat relatif menurun. Hasil wawancara dengan beberapa penyuluh terungkap bahwa motivasi kerja penyuluh pertanian rendah. Selain itu, kemampuan dan keterampilan mereka juga kurang memadai (hasil prasurvai).

Penetapan daerah penelitian berdasarkan beberapa pertimbangan. Kabupaten Indramayu dikenal sebagai daerah yang memiliki luas lahan padi dan produksi padi terbesar di Jawa Barat. Kabupaten Bandung sebagai daerah penghasil padi terkemuka di daerah tengah dan sebagai pusat pemasaran hasil pertanian dan dekat dengan Kota Bandung, sebagai pusat pertumbuhan ekonomi Jawa Barat. Kemudian, Kabupaten Tasikmalaya dipilih dengan pertimbangan, daerah ini merupakan penghasil padi terkemuka di daerah dataran tinggi bagian Selatan Jawa Barat.

Keadaan yang dialami penyuluh pertanian di ketiga daerah tersebut, seperti yang telah dikemukakan di atas, perlu diketahui penyebabnya, baik dari faktor personal maupun dari faktor situasional. Berdasarkan penelitian-penelitian yang ada, sampai sekarang belum diketahui secara pasti, apakah faktor yang mempengaruhi perilaku komunikasi penyuluh pertanian di Jawa Barat dan jika berpengaruh faktor apa yang dominan. Berkaitan dengan hal ini, diperlukan suatu penelitian yang mendalam untuk mengungkapkan faktor-faktor yang mempengaruhi perilaku komunikasi penyuluh pertanian tersebut, baik faktor personal maupun faktor situasional.

\subsection{Perumusan Masalah}

(1) Adakah pengaruh faktor personal penyuluh pertanian terhadap perilaku komunikasi penyuluh pertanian?

(2) Adakah pengaruh faktor situasional penyuluh pertanian terhadap perilaku komunikasi penyuluh pertanian?
(3) Adakah pengaruh faktor personal dan faktor situasional penyuluh pertanian secara bersama-sama terhadap perilaku komunikasi penyuluh pertanian?

\subsection{Tujuan Penelitian}

(1) Untuk memperoleh gambaran yang jelas mengenai kontribusi faktor personal terhadap perilaku komunikasi penyuluh pertanian.

(2) Untuk memperoleh gambaran yang jelas mengenai kontribusi faktor situasional terhadap perilaku komunikasi penyuluh pertanian.

(3) Untuk memperoleh gambaran yang jelas mengenai kontribusi faktor personal dan faktor situasional secara bersama-sama terhadap perilaku komunikasi penyuluh pertanian.

\section{Telaah Pustaka}

Fokus penelitian ini adalah perilaku komunikasi. Perilaku komunikasi pada dasarnya merupakan perilaku manusia dalam kegiatankegiatan komunikasi. Chaplin (1993:53), mendefinisikan perilaku manusia sebagai "sebuah konsep yang luas, yakni segala sesuatu yang dilaksanakan atau dialami seseorang. Dalam pengertian yang lebih sempit, perilaku dapat dirumuskan hanya mencakup reaksi yang dapat diamati secara umum atau obyektif.

Proses mental yang terjadi dalam diri manusia tidak dapat kita amati secara langsung, oleh karena itu, kita hanya dapat menarik kesimpulan mengenai apa yang menyebabkan seseorang bertingkah laku tertentu berdasarkan apa yang ditampilkan orang tersebut. Perilaku manusia sering pula disebut tingkah laku, yang berbentuk aktivitas seseorang atau tindakan-tindakan seseorang dalam rangka bereaksi terhadap rangsang atau stimulus. Stimulus dapat berasal dari dirinya sendiri atau dari luar (lingkungan). Hubungan stimulus dengan tindakan merupakan hubungan sebab akibat. Kekuatan yang mempengaruhi perilaku manusia, tidak hanya kekuatan yang berasal dari lingkungannya saat ini, tetapi juga pengalaman masa lalu dan juga pengaruh dari masa depan. 
Tingkah laku manusia juga dipengaruhi oleh kekuatan dari dirinya sendiri. Individu memiliki minat, insight, emosi, pikiran, dan motif yang mewarnai tindakannya. Semua ini akan menggerakkan aktivitas manusia, termasuk aktivitas komunikasi dan aktivitas lainnya.

Perilaku manusia terbentuk karena pengaruh internal dan eksternal, dikemukakan juga oleh Rotter (Sumantri, 2001: 77). Manusia tidak hanya bereaksi terhadap situasi eksternal, tetapi juga bereaksi terhadap situasi internal.

Munculnya suatu perilaku tertentu, tidak semata-mata dirangsang oleh stimulus luar ataupun situasi eksternal, tetapi juga ditentukan oleh pemilihan kognitif secara sadar terhadap berbagai alternatif tingkah laku yang disesuaikan dengan persepsinya terhadap situasi eksternal tersebut. Konsepsi ini, menimbulkan teori psikologi kognitif yang merupakan grand theory dari penelitian ini. Teori psikologi kognitif memandang manusia sebagai makhluk yang aktif mengorganisasikan dan mengolah stimuli yang diterimanya. Frege menulis, "Pengaruh seseorang pada yang lain, kebanyakan ditimbulkan oleh pikiran. Kita mengkomunikasikan pikiran" (Rakhmat, 1991:26).

Teori psikologi kognitif lahir sebagai reaksi terhadap teori-teori determinisme, yaitu teori psikoanalisis dan teori behaviorisme. Psikoanalisis menganggap keadaan diri seseoranglah yang akan menentukan perilaku seseorang. Sedangkan teori behaviorisme menganggap keadaan lingkunganlah yang menentukan perilaku seseorang. Jika ada stimulus akan bereaksilah seseorang. Responsnya sangat ditentukan oleh jenis stimulusnya. Stimulus yang menyenangkan diikuti oleh perilaku yang berbeda dari perilaku yang timbul karena stimulus yang tidak menyenangkan.

Pandangan-pandangan determinisme ini tidak memandang manusia seutuhnya. Kelemahan ini memunculkan paham interaksionisme. Menurut paham ini, perilaku terjadi karena adanya interaksi antara faktor individu dan faktor lingkungan. Teori ini mengemukakan bahwa perilaku dianggap sebagai hasil interaksi antara faktor-faktor yang terdapat dalam diri sendiri dan faktor luar. Dengan demikian, manusia dan lingkungannya merupakan kesatuan yang tidak dapat dipisah-pisahkan.

Berkaitan dengan teori psikologi kognitif, dalam penelitian ini, dikemukakan bahwa perilaku komunikasi penyuluh pertanian dipengaruhi tidak saja oleh faktor personalnya tetapi juga oleh faktor situasionalnya. Dengan demikian, perilaku penyuluh pertanian merupakan hasil interaksi dirinya dengan lingkungan tempat dia hidup. Konsepsi ini menimbulkan teori lapangan yang dalam psikologi dikenal dengan field theory, sebagai middle range theory dalam mengkaji perilaku komunikasi penyuluh pertanian. Dalam hal ini, perilaku komunikasi penyuluh pertanian merupakan hasil dari interaksi antara faktor personal dan faktor situasionalnya.

Teori lapangan pertama kali dimunculkan oleh Kurt Lewin pada 1942. Teori ini memberi penekanan pada total situation yang disebutnya sebagai psycological field atau life space, yaitu hasil hubungan individu dengan lingkungannya. Untuk dapat mengerti tingkah laku manusia, kita harus mengetahui bagaimana keadaan individu tersebut yang menyangkut faktor-faktor yang ada dalam diri individu seperti pengalaman, sistem orientasi, dan lain-lain, serta pengetahuan tentang situasi yang ada pada saat itu.

Teori lain, sebagai middle range theory pada penelitian ini, adalah teori yang dikemukakan oleh Edward E. Sampson yang menyatakan bahwa perilaku manusia dapat dikaji melalui dua perspektif yang mempengaruhi perilaku manusia, yaitu person centered perspective dan situation centered perspective (Edward E. Sampson, 1976: 3). Perspektif yang berpusat pada persona, mengkaji faktor-faktor internal yang mempengaruhi perilaku manusia. Termasuk dalam faktor ini adalah faktor biologis dan faktor sosiopsikologis. Sedangkan perspektif yang berpusat pada situasi, mengkaji faktor-faktor eksternal yang mempengaruhi perilaku manusia. Termasuk dalam faktor ini adalah faktor situasional.

Manusia adalah makhluk sosial. Dari proses sosial ia memperoleh beberapa karakteristik yang mempengaruhi perilakunya. Dalam penelitian ini, perilaku penyuluh pertanian dipengaruhi oleh 
berbagai faktor, baik internal maupun eksternal . Faktor internal meliputi faktor personal yang terdiri dari kemampuan, pengalaman, persepsi dan motif, sedangkan faktor eksternal berupa kelembagaan penyuluhan, sarana kerja, wilayah binaan, dan tempat tinggal. Perilaku penyuluh merupakan faktor penting dalam menganalisis sumber informasi yang secara langsung mendukung pengembangan tugasnya. Hal ini sesuai dengan pendapat Schramm yang menyebutkan bahwa, peranan komunikasi dalam perkembangan sosial ekonomi individu adalah: (1) memberi informasi, (2) membantu mempercepat pengambilan keputusan, (3) berperan dalam proses pengajaran keterampilan (Asngari, 1996: 10).

Sebagai applied theory, teori yang digunakan Emmert dapat dijadikan pegangan dalam penelitian ini. Philip Emmert (1989: 93-94) mengatakan bahwa:

"One of the interesting distinctions we can make regarding the variables that have been measured is the distinction between those variables we can observe and those we cannot observe”. Tampak di sini, Emmert membedakan variabel yang telah diukur, yaitu variabel yang dapat diamati dan tidak dapat diamati. Selanjutnya, perilaku komunikasi yang dapat diukur adalah semua gejala yang timbul dan dapat diamati, sedangkan variabel yang tidak dapat diamati, dapat diberi contoh seperti sikap, persepsi, kecerdasan, makna, dan kepribadian.

Perilaku komunikasi yang tampak disebut juga overt behavior dan perilaku yang tidak tampak disebut covert behavior. Perilaku baik yang tampak maupun tidak tampak ada yang alami (innate) dan ada yang operan (operant). Sebagian besar perilaku manusia berupa perilaku operan, yakni perilaku yang dibentuk atau dipelajari sedangkan perilaku alami berupa gerakan-gerakan refleks, insting atau pembawaan yang berkaitan dengan kepribadian yang dibawa sejak lahir walaupun hal ini dapat diubah. Perilaku komunikasi sebagai bagian dari perilaku pada umumnya merupakan aktivitas baik yang tampak maupun yang tidak tampak dan bersifat operan.

Dalam penelitian ini, peneliti menggunakan konsep perilaku komunikasi yang lebih mendalam khususnya perilaku komunikasi penyuluh pertanian. Perilaku komunikasi penyuluh pertanian adalah perbuatan atau tindakan komunikasi seorang penyuluh dalam melaksanakan tugasnya, yang dapat diketahui dari pengetahuan, keterampilan komunikasi dan intensitas komunikasinya. Perilaku komunikasi itu terdiri dari perilaku atas process area (metode penyuluhan) dan perilaku atas content area (materi penyuluhan).

\section{Metodologi Penelitian}

Desain penelitian ini adalah deskriptifeksplanatoris yang menggunakan dua metode penelitian yang dilakukan secara berdampingan, yaitu metode penelitian deskriptif dan metode penelitian eksplanatoris melalui survai. Metode penelitian deskriptif secara umum bertujuan untuk mendapatkan gambaran tentang karakteristik personal dan situasional penyuluh pertanian, perilaku komunikasinya dan faktor-faktor kognisi, afeksi dan perilaku petani.

Metode penelitian eksplanatoris digunakan untuk mendapatkan data mengenai pengaruh faktor personal dan faktor situasional terhadap perilaku komunikasi penyuluh. Metode ini menggunakan sampel yang bertujuan menguji hipotesis, yang telah dirumuskan sebelumnya (testing research). Data hasil penelitian yang menggunakan kuesioner, dianalisis dengan analisis statistik deskriptif dan statistik inferensial, sedangkan data hasil penelitian yang diperoleh melalui wawancara, digunakan sebagai pelengkap informasi untuk pembahasan secara kualitatif.

\section{Hasil dan Pembahasan}

Menurut perhitungan statistik, pengaruh faktor personal dan faktor situasional terhadap perilaku komunikasi penyuluh pertanian diperoleh sebesar $68.22 \%$. Hal ini menandakan adanya pengaruh yang besar dibandingkan pengaruh lainnya yang hanya $31.78 \%$. Hasil pengujian ini memberikan gambaran bahwa terdapat pengaruh yang signifikan antara faktor personal dan faktor situasional terhadap perilaku komunikasi penyuluh 
pertanian. Penelitian ini memperkuat teori yang dikemukakan oleh Kurt Lewin yang mengatakan bahwa tingkah laku manusia merupakan hasil interaksi diri individu dengan lingkungannya. Menurut Lewin, dalam kehidupannya, manusia tidak dapat dipisahkan dari lingkungan tempat dia berada. Manusia dan lingkungannya akan saling mempengaruhi dalam rangka mencapai keseimbangan. Hal ini akan tercermin dalam tingkah lakunya. Dasar dari teori ini, menekankan pada life space (lapangan kehidupan). Lapangan kehidupan seseorang terdiri dari individu itu sendiri dan lingkungannya. Lingkungan di sini mempunyai arti yang luas, yaitu segala sesuatu yang berada di luar individu baik fisik maupun psikologis. Interaksi individu dengan lingkungan, akan mempengaruhi struktur kognitif individu sehingga memungkinkan terjadinya perilaku tertentu. Dari pengalaman inilah frame of reference terbentuk sebagai dasar di dalam dia berinteraksi lebih lanjut.

Berdasarkan wawancara dan pengamatan di lapangan terungkap bahwa kedua faktor itu memang berpengaruh terhadap perilaku komunikasi penyuluh pertanian. Faktor personal memiliki sumbangan yang paling besar dibandingkan dengan faktor situasional. Faktor personal secara total berpengaruh sebesar 39.81 $\%$ terhadap perilaku komunikasi penyuluh pertanian, sedangkan faktor situasional secara total berpengaruh sebesar $28.41 \%$ terhadap perilaku komunikasi penyuluh pertanian.

Faktor personal yang terdiri dari kemampuan, pengalaman, motif dan persepsi yang cukup baik dari penyuluh pertanian, dapat mengimbangi keterbatasan sarana kerja dan status kelembagaan penyuluhan.

Dari jawaban responden, dapat dikemukakan bahwa aspek kemampuan yang merupakan bagian dari faktor personal mendapat nilai skor 66 . Walaupun termasuk dalam kategori cukup baik. namun apabila dikaji secara khusus, terdapat item yang menunjukkan ketidakmampuan penyuluh pertanian dalam hal untuk menjawab setiap pertanyaan dari petani (item no. 34). Sebanyak 77 $\%$ petani menjawab kurang setuju, apabila penyuluh dianggap dapat menjawab setiap pertanyaan dari petani. Berdasarkan pengamatan peneliti, ketidakmampuan penyuluh tersebut, berkaitan tentang materi yang belum dikuasai oleh penyuluh, sehingga petani tidak puas atas jawaban penyuluh. Ketidakmampuan penyuluh tersebut. disebabkan karena materi itu belum pernah diperolehnya pada waktu pelatihan. Keadaan seperti ini terjadi di Kabupaten Bandung dan Kabupaten Tasikmalaya. Pada dua kabupaten ini, sejak BIPP dibubarkan, pelatihan untuk para penyuluh pertanian sangat jarang dilakukan. Hal ini berbeda pada Kabupaten Indramayu yang selalu mengadakan pelatihan secara rutin dan terjadwal.

Kemampuan yang berbeda dari penyuluh pertanian menyebabkan perbedaan pula pada perilakunya. Para penyuluh di Kabupaten Indramayu secara umum lebih banyak mendapatkan pelatihan secara rutin dan terjadwal. Hal ini menyebabkan kemampuan mereka lebih baik Kemampuan yang ingin diketahui dalam penelitian ini, antara lain, penguasaan penyuluh tentang materi yang disampaikan, penguasaan tentang karakterisitik khalayak, penguasaan tentang bahasa.

Di tiga kabupaten yang diteliti, penguasaan penyuluh tentang materi yang disampaikan cukup baik. Persoalan yang timbul adalah kadang-kadang penyuluhan yang disampaikan tidak tepat waktunya. Misalnya, pada waktu musim kemarau 2002, petani yang mengalami kekeringan maupun kerugian akibat musim kemarau memperoleh bantuan dari pemerintah berupa benih untuk musim tanam selanjutnya, namun karena bantuan itu datang setelah musim tanam maka penyuluhanpun dilakukan pada saat bantuan itu datang.

Di beberapa Kecamatan di Kabupaten Tasikmalaya seperti di Kecamatan Rajapolah, bantuan benih yang diberikan kepada petani, tidak sesuai dengan keadaan lahan petani. Di sana, lahannya tadah hujan, benih yang diberikan seharusnya berumur pendek, tetapi yang diberikan yang berumur panjang. Selain itu petani sudah mulai tanam, benih baru datang. Begitu juga di Kecamatan Cigalontang mayoritas lahan berada 
di daerah perbukitan 700 meter diatas permukaan laut, benih yang diberikan adalah varietas unggul yang tidak cocok untuk daerah tersebut.

Di Kabupaten Indramayu hal serupa terjadi, benih padi yang diberikan tidak tepat waktu dan benih yang diberikan adalah Cisadane dan IR-64 yang tidak begitu disukai petani karena rentan terhadap wereng.

Mencermati kejadian-kejadian seperti itu, tampaknya pemerintah belum sepenuh hati membantu kesulitan petani. Berkaitan dengan kemampuan, di daerah penelitian, kelemahan yang dirasakan petani adalah pengetahuan dan kemampuan dalam hal pemasaran produksi. Mereka menginginkan pada waktu panen, harga tidak jatuh. Kelemahan ini belum bisa diatasi oleh penyuluh karena penyuluh sendiri tidak mempunyai kemampuan yang memadai untuk mengatasinya. Tentang masalah ini, selama penyuluhan masih tetap berorientasi pada peningkatan produksi pertanian dan penyuluhan tidak ikut mengarahkan pemasaran hasil-hasil pertanian, maka sulit dikatakan bahwa penyuluhan pertanian telah dapat meningkatkan kesejahteraan petani.

Kelemahan kemampuan dalam hal materi, juga terlihat pada saat petani menanyakan hal baru yang pernah dilihatnya di media televisi seperti tomat yang buahnya lebih besar daripada tomat biasa. Sehubungan penyuluh belum mengetahui dan belum menguasai tentang seluk-beluk tanaman tersebut, maka pertanyaan petani tersebut tidak dapat dijawab. Hal ini tidak akan terjadi, apabila penyuluh mendapatkan pelatihan-pelatihan secara rutin atau memperoleh informasi-informasi aktual dari media cetak sehingga dia dapat mengikuti perkembangan dunia pertanian yang bermanfaat guna membantu petani.

Melihat upaya yang harus dilakukan ini, tampak bahwa penyuluh dituntut untuk meningkatkan kemampuannya dengan berbagai cara. Apabila mereka tidak mendapatkan pelatihanpelatihan yang memadai, masih bisa meningkatkan kemampuan melalui berbagai media ataupun literatur yang memerlukan dana lebih sedikit dibandingkan ikut dalam pelatihan atau kursus.
Dana dapat dikeluarkan lebih sedikit lagi, jika penyuluh dapat secara bersama-sama menanggung pembelian majalah pertanian misalnya, yang kemudian dapat membacanya secara bergantian. Dengan demikian, pendapat penyuluh yang mengatakan bahwa dana merupakan faktor penghambat untuk meningkatkan kemampuannya, tidaklah tepat. Ternyata yang paling penting adalah adanya kemauan untuk meningkatkan kemampuan dan kreativitas untuk mengatasi hambatan dalam meningkatkan kemampuan tersebut.

Pengalaman sebagai penyuluh dapat membentuk perilaku komunikasi mereka dalam melaksanakan tugas. Pengalaman yang cukup dalam pelatihan misalnya, akan memudahkan mereka membuat program penyuluhan yang benarbenar dibutuhkan petani, menerapkan metode penyuluhan yang tepat dan hasilnya dapat dirasakan petani serta memiliki keterampilanketerampilan yang dibutuhkan. Pengalaman penyuluh pertanian pada item nomor 2 , mengungkapkan bahwa sebagian besar mereka (66 $\%)$, menyatakan lamanya waktu pelatihan tidak mencukupi untuk melaksanakan tugas penyuluhan. Hal ini berkaitan juga dengan kurangnya kemampuan mereka dalam menjawab pertanyaan petani karena terbatasnya kesempatan untuk mendapatkan pelatihan. Metode penyuluhan pun lebih banyak menggunakan pendekatan kelompok dalam bentuk pertemuan, diskusi kelompok dan demonstrasi. Padahal, berdasarkan wawancara dengan petani, mereka lebih membutuhkan kursus tani atau sekolah lapangan karena dalam pertemuan dan sejenisnya, materi yang diberikan dianggap sudah mereka kuasai dan timbul rasa kejenuhan. Jika kursus tani atau sekolah lapang, banyak menambah wawasan dan keterampilan yang sebelumnya minim sekali seperti pengetahuan tentang hama tanaman. Pengetahuan tentang hama, banyak diperoleh pada Sekolah Lapangan Pengendalian Hama Terpadu (SPLHT).

Gambaran tentang kemampuan penyuluh dan metode penyuluhan yang digunakan sebagaimana telah dijelaskan, menunjukkan bahwa gaya pelatihan perlu direvisi, tidak lagi terbatas pada 
penyampaian pesan, tetapi mencoba untuk mengembangkan kreativitas

Keadaan petani umumnya, yang tinggal di pedesaan memiliki fasilitas sosial yang serba kurang, keadaan sosial ekonomi yang tidak tinggi dan tingkat pendidikan mereka yang umumnya rendah, semua ini merupakan persoalan yang dihadapi penyuluh di lapangan. Pengalaman penyuluh dalam membantu mengatasi masalah petani cukup baik, yaitu dalam hal memberi informasi yang dibutuhkan dan sebagai penghubung atau jembatan penyaluran bantuan yang datang dari pemerintah maupun swasta.

Motif merupakan kekuatan pendorong yang ada pada individu. Terdapat dua jenis kekuatan tersebut, yaitu kekuatan positif dan kekuatan negatif(Krech, 1962: 69; Schiffman dan Kanuk 1994: 97).

Dalam hal motif yang menyangkut dana, mayoritas responden (58\%) menyatakan bahwa dukungan dana operasional penyuluhan yang mencukupi, dapat meningkatkan motif penyuluh dalam melaksanakan tugas. Berdasarkan wawancara dan pengamatan di lapangan, dapat diungkapkan bahwa dana operasional yang tidak memadai sebagai penyebab mereka enggan mengadakan kunjungan secara terjadwal dan rutin ke petani. Namun, hal ini terjadi di Kabupaten Bandung dan Kabupaten Tasikmalaya, sedangkan di Kabupaten Indramayu tidak ditemui hal seperti itu.

Hasil penelitian menunjukkan, secara umum motif penyuluh berada dalam kategori cukup baik. Namun, ada pernyataan yang termasuk dalam kategori kurang baik, yaitu menyangkut motifuntuk berprestasi seperti yang telah disebutkan di atas. Para penyuluh pertanian masih mengandalkan dana untuk keberhasilan melaksanakan tugasnya. Mereka kurang mempunyai dorongan yang kuat untuk mengatasi kekurangan dana. Jika mereka mempunyai dorongan yang kuat, maka akan timbul pemikiran-pemikiran kreatif untuk mengatasi masalah dana tersebut.

Berdasarkan uraian konsep motif berprestasi, tampak bahwa para penyuluh belum dapat mengendalikan ataupun mengatasi persoalan dana dalam melaksanakan tugasnya, sehingga mereka enggan untuk mengadakan kunjungan secara terjadwal dan rutin ke petani.

Aspek lain dari faktor personal adalah persepsi. Persepsi penyuluh tentang petani dan program penyuluhan dapat dikategorikan cukup baik dengan skor masing-masing 75. Sedangkan persepsi penyuluh tentang kelembagaan penyuluhan memiliki nilai skor yang lebih rendah, yaitu 57. Dari item yang memberi pernyataan tentang lembaga penyuluhan memiliki kemampuan untuk meningkatkan kualitas penyuluh, $62 \%$ responden menjawab ketidaksetujuan mereka, dengan rincian, kurang setuju $40 \%$ dan $22 \%$ menyatakan tidak setuju. Item yang memberi pernyataan tentang lembaga penyuluhan memahami permasalahan yang dihadapi penyuluh, mendapat jawaban yaitu $65 \%$ menyatakan ketidaksetujuannya, dengan rincian, $44 \%$ kurang setuju dan $21 \%$ menyatakan tidak setuju. Sedangkan item pernyataan tentang lembaga penyuluhan menerima aspirasi petani yang disampaikan melalui penyuluh, mendapat jawaban $62 \%$ responden menjawab ketidaksetujuan mereka, dengan rincian, kurang setuju $40 \%$ dan $22 \%$ menyatakan tidak setuju.

Operasionalisasi konsep persepsi di lapangan, menemukan bahwa penyuluh pertanian menganggap petani dapat mengerti, memahami, dan mau melakukan apa yang dianjurkan dalam penyuluhan. Karena itu, penyuluh pertanian selalu memberikan motivasi ataupun dorongan kepada petani untuk semaksimal mungkin menggunakan teknologi usaha tani yang dianjurkan sehingga keiinginan petani untuk memperoleh hasil yang berkualitas dapat terpenuhi. Dalam hal program penyuluhan, penyuluh beranggapan program penyuluhan yang ada, sesuai dengan keadaan, kebutuhan petani dan sesuai juga dengan tingkat pengetahuan dan kemampuan petani. Oleh karena itu penyuluhan yang dilaksanakan, telah disesuaikan dengan situasi dan kondisi petani untuk memenuhi kebutuhan petani.

Namun berbeda dengan persepsi penyuluh tentang petani dan program penyuluhan sebagaimana dijelaskan, hasil penelitian persepsi 
penyuluh tentang kelembagaan penyuluhan kurang baik dibandingkan persepsi mereka tentang petani dan program penyuluhan. Hal ini disebabkan lembaga penyuluhan di Kabuapaten Bandung dan Kabupaten Tasikmalaya yang telah dilebur ke dalam Dinas-Dinas itu, masih menganggap tugas penyuluh tidak begitu penting.

Dalam wawancara dengan penyuluh terungkap bahwa pada saat seminar pertanian, Bupati Bandung pernah mengeluarkan pernyataan tentang keberadaan penyuluh. Bupati mengatakan bahwa ada atau tidak adanya penyuluh, tidak berpengaruh kepada petani. Petani tetap menanam padi. Pernyataan ini menjelaskan ketidaktahuan Bupati Bandung tentang penyuluhan, dan merupakan bahan evaluasi bagi penyuluh tentang keberadaannya di lapangan. Sikap seperti ini, menyebabkan kurang pedulinya institusi tersebut pada pembinaan sumberdaya penyuluh. Dampaknya persepsi penyuluh terhadap institusinya tidak begitu baik.

Kelembagaan penyuluhan berperan penting untuk mewujudkan fungsi penyuluhan yang, di antaranya, sebagai penghubung antara petani dengan pelayanan, informasi, dan pemasaran. Konsekuensi dari fungsi ini, lembaga penyuluhan hendaknya dapat menerima aspirasi petani melalui aparat penyuluh. Aspirasi yang berkembang pada waktu penelitian, petani menginginkan pemasaran hasil produksi dapat terjamin dengan harga wajar, kemudian untuk meningkatkan mutu produksi, harga pupuk dapat terjangkau serta perlunya diperluas sekolah lapangan. Namun, aspirasi petani tersebut belum banyak membuahkan hasil. Setiap panen raya petani selalu menghadapi harga yang rendah, harga pupuk tidak pernah turun sehingga terjangkau oleh petani. Hanya ada beberapa sekolah lapangan yang ditambah pelaksanaannya.

Komunikasi dan motivasi merupakan faktor penting untuk menjaga kelangsungan fleksibilitas kelembagaan penyuluhan. Kelembagaan dapat mencapai berbagai tujuan dan kelompok sasaran melalui berbagai cara baru, jika kelembagaan bisa berpacu dengan perkembangan baru di bidang pertanian. Hal ini menghendaki suatu program perkembangan kelembagaan yang berkesinambungan dan kebijaksanaan yang menciptakan kesempatan bagi penyuluh untuk berkembang dan memberi penghargaan bagi mereka yang menggunakan kesempatan tersebut dengan efektif. Terkait dengan ini, seyogianyalah lembaga penyuluhan mempunyai kemampuan untuk meningkatkan kualitas penyuluh dan memahami permasalahan yang dihadapi penyuluh.

Dalam penelitian ini dikaji pula pengaruh faktor situasional berupa status kelembagaan penyuluhan dan sarana kerja. Dari jawaban responden tentang pernyataan faktor situasional, secara umum dapat dikategorikan cukup baik dengan skor 72. Namun, pernyataan tentang, lembaga penyuluhan dapat membangun satu kesatuan korps, satu kesatuan manajemen yang membawa misi penyuluhan pertanian, mendapat jawaban, yaitu $64 \%$ responden mengungkapkan ketidaksetujuan atas pernyataan tersebut dengan rincian:.kurang setuju $49 \%$ dan tidak setuju atas pernyataan tersebut sebesar $15 \%$.

Berkaitan dengan membangun kesatuan korps, Siagian (1982: 72) mengemukakan bahwa tumbuh, berkembang, dan terpeliharanya semangat kerjasama yang harmonis dan mantap, merupakan hal yang penting dalam suatu organisasi. Kerja sama ini dapat efektif apabila anggota organisasi tidak terpecah-pecah dalam satuan tugas yang berbeda padahal subjeknya sama dengan kegiatan yang relatif sama pula.

Dalam konsep perilaku komunikasi, Berlo (1960: 49), menyatakan bahwa ketepatan komunikasi yang dilakukan komunikator dipengaruhi juga oleh lapisan sosial, dalam hal ini organisasi tempat penyuluh pertanian bekerja. Status organisasi penyuluhan yang dibubarkan, seperti di Kabupaten Bandung dan Kabupaten Tasikmalaya, memberikan dampak terhadap kesatuan korps penyuluhan. Mereka merasa kehilangan induk dan hubungan antarpenyuluh, terutama hubungan kerja tidak lagi harmonis karena penyuluh sudah terpecah ke dalam instansiinstansi.

Dalam kaitan dengan organisasi penyuluhan yang mandiri, Slamet (1992), mengatakan, program penyuluhan yang efektif dan efisien dapat 
dikembangkan oleh tenaga-tenaga profesional di bidang penyuluhan pembangunan, dan hal ini hanya dimungkinkan apabila program itu terwadahi dalam suatu sistem kelembagaan penyuluhan dan pelaksanaannya didukung oleh tenaga-tenaga profesional di bidang penyuluhan. Program semacam itu, berdasarkan empiris, perlu dilandasi oleh kemauan politik yang kuat untuk menjamin adanya kesepakatan semua pihak yang terkait (Sumardjo, 1999: 33).

Dalam wawancara dengan beberapa penyuluh, terungkap bahwa mereka menginkan kembali adanya kesatuan korps penyuluhan, dengan cara membentuk organisasi penyuluhan yang baru semacam dinas atau kantor untuk wadah mereka bersatu. Alasan yang mereka ajukan, selain hubungan kerja antarpenyuluh tidak harmonis, juga minimnya dana untuk program penyuluhan. Bila dibentuk organisasi penyuluhan yang baru, penyuluh dapat mencari sendiri peluang dana dari pemerintah pusat.

Mengenai dana ini, peneliti pernah mewawancarai penyuluh pertanian di Kabupaten Indramayu yang bernaung pada Kantor Informasi Penyuluhan Pertanian (KIPP). Mereka mengatakan, memang ada dana bantuan penyuluhan dari pemerintah pusat. Dana itu hanya diberikan kepada penyuluh yang mempunyai wadah dalam suatu organisasi penyuluhan. Selain dana penyuluhan, pemerintah pusat juga memberikan majalah penyuluh pertanian, tabloid pertanian, brosur, dan leaflet.

Suatu organisasi penyuluhan yang dapat menghimpun semua penyuluh pertanian dari berbagai sektor seperti yang telah dilakukan sebelumnya (BIPP), dapat lebih memokuskan program-program kerja, sehingga kinerja penyuluh lebih optimal. Selain itu, memudahkan petani untuk berhubungan dengan penyuluh karen semua penyuluh dari berbagai sektor yang berada di tingkat kecamatan, berkantor di tempat yang sama yaitu di BPP (Balai Penyuluh Pertanian).

Keuntungan lain, penyuluh dapat leluasa menjawab pertanyaan petani tentang materi di luar keahliannya, sepanjang dia mampu. Hal ini berbeda jika penyuluh sudah terkotak-kotak sesuai keahliannya. Pada situasi seperti ini, penyuluh yang mendapat pertanyaan tentang materi di luar keahliannya. Misalnya, penyuluh pangan mendapat pertanyaan tentang ternak. Penyuluh tersebut, walaupun mampu menjawab, dia tidak akan melakukannya karena beranggapan ada penyuluh lain yang lebih berwenang. Hal seperti ini merugikan petani karena dia harus menunggu penyuluh lain yang berwenang. Padahal, sejak awal, walaupun seorang penyuluh mempunyai latar belakang keahlian tertentu, dia juga diberi pengetahuan dan pelatihan tentang materi di luar keahliannya. Hal ini dilakukan karena realitas petani di lapangan, tidak hanya menanam padi tetapi juga bertanam sayuran, memelihara ternak dan lain sebagainya.

Semua pertanyaan tentang sarana kerja yang tersedia, mendapat jawaban dalam kategori kurang baik, yaitu dengan skor 34. Hal ini menandakan bahwa sarana kerja yang tersedia tidak memadai untuk melaksanakan tugas penyuluhan. Sarana kerja itu berupa sarana kerja berbentuk media elektronik, media cetak, sarana transportasi ke lapangan, dan dana transportasi.

Hasil pengamatan di lapangan menemukan bahwa sarana kerja yang tidak memadai ini memberikan dampak terhadap perilaku komunikasi penyuluh, yaitu keengganan mereka untuk mengunjungi petani dengan alasan tidak adanya dana transportasi. Kenyataan ini sesuai dengan konsep perilaku organisasi yang dikemukakan oleh Sondang P. Siagian yang mengemukakan bahwa kondisi kerja dapat mempengaruhi perilaku anggota organisasi. Kondisi kerja ini meliputi tersedianya sarana kerja yang memadai (Siagian, 1982: 64). Penelitian Herzberg juga memperkuat hasil pengamatan diatas. Herzberg menyebutkan bahwa kondisi kerja yang tidak memadai menyebabkan ketidakpuasan kerja (Stoner, 1996: 144).

Beban kerja penyuluh pertanian pada tiga kabupaten yang diteliti, tidak sebanding dengan sarana kerja yang ada, terutama sarana transportasi. Jumlah penyuluh sangat terbatas, sementara jumlah desa banyak dan sarana serta dana transportasi sangat terbatas. Misalnya, Kabupaten Tasikmalaya yang memiliki 151 penyuluh pertanian 
harus melayani petani di 348 desa, atau rata-rata seorang penyuluh melayani dua sampai tiga desa. Menurut Kepala Dinas Pertanian Kabupaten Tasikmalaya, setiap penyuluh pertanian harus mampu bekerja untuk luas lahan 1.874 hektar. Kondisi seperti ini menyebabkan intensitas komunikasi penyuluh pada petani tidak maksimal. Padahal, intensitas komunikasi merupakan hal penting untuk mencapai keberhasilan penyampaian pesan. Krech dkk (1962: 20), menjelaskan bahwa pada dasarnya kognisi individu terorganisir secara selektif. Hanya informasi yang menonjol saja yang mendapat perhatian. Informasi yang kurang menonjol atau kurang tingkat intensitasnya, kurang mendapat tanggapan dari kognisi. Dengan penjelasan itu, tampak bahwa kondisi sarana kerja yang tidak memadai berpengaruh terhadap intensitas komunikasi yang dilakukan penyuluh.

Sarana kerja penyuluhan merupakan juga media penyuluhan. Dalam proses komunikasi pada penyuluhan, diperlukan media penyuluhan, yaitu saluran yang dapat menghubungkan penyuluh, materi penyuluhan dan petani yang memerlukan penyuluhannya. Pada keadaan seperti ini, baik petani maupun penyuluh akan melakukan komunikasi dua arah.

\section{Kesimpulan dan Saran}

\subsection{Kesimpulan}

(1) Secara umum, hasil penelitian ini mengungkapkan bahwa ada interaksi antara faktor personal dengan faktor situasional. Kedua faktor tersebut mempengaruhi perilaku komunikasi penyuluh pertanian. Dalam penelitian ini, terungkap bahwa faktor personal penyuluh pertanian lebih dominan mempengaruhi perilaku komunikasinya dibandingkan dengan faktor situasional.

(2) Pengujian terhadap hipotesis penelitian, memberikan hasil sebagai berikut:

(a) Faktor personal berpengaruh terhadap perilaku komunikasi penyuluh pertanian. Kenyataan ini ditunjukkan oleh besarnya koefisien jalur yang mempengaruhi perilaku komunikasi penyuluh pertanian.

(b) Faktor situasional berpengaruh terhadap perilaku komunikasi penyuluh pertanian. Adanya pegaruh ini, ditunjukkan oleh besarnya koefisien jalur yang mempengaruhi perilaku komunikasi penyuluh pertanian.

(c) Faktor personal dan faktor situasional secara bersama-sama maupun secara terpisah berpengaruh terhadap perilaku komunikasi penyuluh pertanian. Dalam penelitian ini, faktor personal penyuluh pertanian lebih dominan mempengaruhi perilaku komunikasinya dibandingkan dengan faktor situasional. Dengan demikian, aspek kelembagaan penyuluhan dan sarana kerja bukanlah kendala yang paling menentukan terjadinya perilaku komunikasi penyuluh yang positif untuk mencapai keberhasilan penyuluhan. Faktor personal penyuluh yang meliputi kemampuan, pengalaman, motif, dan persepsilah yang paling menentukan perilaku komunikasi penyuluh yang positif untuk tercapainya keberhasilan penyuluhan.

(3) Di bidang pertanian, banyak dan beragamnya informasi yang diperoleh, dapat memberi keuntungan, baik bagi pengetahuan penyuluh maupun keuntungan usaha bagi petani. Pada tiga kabupaten yang diteliti, aksesibilitas penyuluh dan petani terhadap informasi pertanian masih didominasi oleh komunikasi interpersonal. Akses informasi pertanian terhadap media cetak dan media elektronik, baik penyuluh maupun petani sangatlah minim. Berdasarkan penemuan di lapangan seperti yang telah dijelaskan, dapat digambarkan bahwa, baik sistem komunikasi maupun akses terhadap informasi pertanian masih bersifat tradisional, belum memanfaatkan teknologi komunikasi yang berkembang pesat saat ini.

\subsection{Saran}

\subsubsection{Saran Gunalaksana}

(1) Faktor personal penyuluh sebagai faktor dominan dalam menumbuhkan perilaku komunikasi penyuluh pertanian yang diharapkan, memerlukan pembinaan motivasi 
agar mereka bisa berperan lebih positif. Hal ini dapat ditempuh, antara lain, melalui pelatihan pembinaan motivasi untuk meningkatkan prestasi. Selain itu, perlu juga peningkatan pelatihan kemampuan, bukan saja dari aspek teknis pertanian, tetapi lebih banyak kepada aspek social engineering dan menyediakan anggaran penyuluhan yang memadai serta adanya kepastian karier fungsional penyuluh.

(2) Faktor situasional berupa program pada kelembagaan penyuluhan, masih cenderung bersifat sentralistik. Karena itu, perlu desentralisasi kelembagaan penyuluhan sampai ke tingkat desa sehingga pendekatannya tidak lagi cenderung ke top down dan farmer last, tetapi sudah menjadi bottom up dan farmer first. Dengan demikian, penyelenggaraan penyuluhan pertanian harus berawal dari kebutuhan dan keputusan petani.

(3) Perilaku komunikasi penyuluh pertanian yang berkaitan dengan intensitas komunikasi dengan petani, materinya masih menekankan perlunya meningkatkan produk usaha tani dan kurang memperhatikan pendapatan atau keuntungan, sehingga seringkali petani memperoleh produk yang tinggi namun keuntungan sedikit atau malah rugi. Oleh karena itu, sudah saatnya sekarang memperhatikan dan memperhitungkan dengan baik masalah pendapatan dan keuntungan itu. Konsekuensinya penyuluh pertanian harus berorientasi dirinya ke arah agribisnis. Mereka harus banyak belajar dan mengembangkan prinsip-prinsip dan teknologi-teknologi yang berkaitan dengan agribisnis.

\subsubsection{Saran Teoretis}

1) Mengingat penelitian keberhasilan penyuluhan dari dimensi komunikasi, khususnya psikologi komunikasi sangat kurang dibandingkan dengan penelitian keberhasilan penyuluhan dari dimensi kebijakan dan ekonomi atau faktor-faktor produksi, maka penelitian ini merekomendasikan bahwa perlu dilakukan penelitian yang sama pada daerah lain di In- donesia dengan menambah unsur budaya setempat.

2) Penelitian ini menggunakan metode kuantitatif. Untuk penelitian selanjutnya dapat dilakukan penelitian sejenis dengan metode kualitatif yang sesuai dengan aspek teoretis maupun metodologis untuk menganalisis permasalahan yang ada dalam penelitian ini.

\section{Daftar Pustaka}

Asngari, Pang S. 1996. Komunikasi, Informasi dan Edukasi dalam Penyuluhan. Bogor: Fakultas Peternakan IPB.

Berlo, David. K. 1960. The Process of Communication. New York: Holt, Rinehart and Winston, Inc.

Chaplin C.P. 1993. Dictionary of Psychology. Terjemahan Kartono Kartini Kamus Lengkap Psikologi. Jakarta: Raja G. Persada.

Dinas Pertanian Tanaman Pangan Kabupaten Bandung. 2000. Laporan Tahunan Tahun 2000 .

Emmert, Philip.1989. Measurement of Communication Behavior. New York: Longman Inc.

Krech, David, Richard S. Crutchfield dan Egerton Ballachey. 1962. Individual in Society. Tokyo: McGraw Hill Kogakusha.

Pusat Dinamika Pembangunan Universitas Padjadjaran dan Kanwil Departemen Pertanian Provinsi Lampung. 2000.Reformasi Kelembagaan Penyuluhan Pertanian dalam Meningkatkan Kinerja Program BIMAS. Bandung.

Rakhmat, Jalaluddin. 1991. Psikologi Komunikasi. Bandung: Remaja Rosdakarya.

Sampson, Edward E, 1976. Social Psychology and Contemporary Society. Toronto: John Wiley and Sons, Inc.

Schiffman. Leon G dan Leslie Lazar kanuk. 1994. Consumer Behavior. London: Prentice Hall International. 
Siagian, Sondang P. 1982. Organisasi, Kepemimpinan dan Perilaku Administrasi. Jakarta: Gunung Agung.

Slamet, R. Margono. 1992. Perspektif Ilmu Penyuluhan Pembangunan Menyongsong Era Tinggal Landas, dalam Penyuluhan Pembangunan di Indonesia Menyongsong Abad XXI. ed. Hubeis, dkk. Jakarta: Pustaka Pembangunan Swadaya Nusantara.
Stoner, James A. dkk. 1996. Manajemen. Jakarta: Prenhallindo.

Sumantri, Suryana. 2001. Perilaku Organisasi. Bandung: Universitas Padjadjaran.

Sumardjo.1999. "Transformasi Model Penyuluhan Pertanian Menuju Pengembangan Kemandirian Petani (Kasus di Provinsi Jawa Barat). Disertasi”. Bogor: Program Pascasarjana IPB. 